Article

\title{
Determination of Hydrogen Transport Behaviour in Boron-Manganese Steels Using Different Methods and Boundary Conditions
}

\author{
Matthias Kuhlmann, Niels Mitzschke and Sven Jüttner *(i) \\ Faculty of Mechanical Engineering, Institute of Material and Joining Technology, Otto von Guericke University \\ Magdeburg, 39106 Magdeburg, Germany; matthias.kuhlmann@ovgu.de (M.K.); niels.mitzschke@ovgu.de (N.M.) \\ * Correspondence: sven.juettner@ovgu.de; Tel.: +49-391-67-58741
}

Received: 30 July 2019; Accepted: 9 September 2019; Published: 12 September 2019

\begin{abstract}
Within the framework of the project "ELOBEV" (research of electrolytic coating systems for joining elements made of high-strength materials) funded by the Federal Ministry of Education and Research, a test methodology for the assessment of the danger of hydrogen-assisted and liquid metal-induced cracking for auxiliary joining elements is being developed. One working point of the project is the determination of the hydrogen transport behaviour in high-strength boron-manganese steels and their coating concepts. Permeation measurements under different boundary conditions are used to characterize the hydrogen transport in 22MnB5 and 37MnB4. The results are validated by thermal desorption analyses with a constant heating rate and an isothermal temperature control. Several methods for the determination of the diffusion velocity are investigated and the determined values are compared with each other.
\end{abstract}

Keywords: quenched and tempered steel; 22MnB5; 37MnB4; diffusion coefficient; thermal desorption analysis; permeation measurement

\section{Introduction}

There is a steadily increasing demand for high-strength and ultra-high-strength materials in industry. One example is the automotive industry, where lightweight materials are used, especially for crash-relevant parts. Here the material 22MnB5 has prevailed [1]. Another field of application for boron-manganese steels are joining elements with high strength requirements [2]. For example, the quenched and tempered steel 37MnB4 can be mentioned here for self-pierce rivets. The use of higher-strength steels also increases the potential for hydrogen-assisted damages. Materials with tensile strengths of more than $1000 \mathrm{MPa}$ are considered endangered [3,4]. In metallic materials, hydrogen can lead to a reduction in ductility up to deformation-free failure (under stress). This fracture mechanism can occur delayed due to hydrogen diffusion, up to several days after completion of components or welded joints. This behaviour, known as hydrogen assisted cold cracking (HACC), requires three prerequisites: The material contains hydrogen, it has a brittle structure and there are tensile stresses or residual stresses in the component [3,5].

\subsection{Hydrogen Absorption}

Hydrogen absorption in metals can take place in a variety of ways and along the entire value chain of the product right up to the customer [6]. One possible process is the absorption of hydrogen from the liquid phase according to the HER (hydrogen evolution reaction) mechanism. The mechanism can take place in both acidic and alkaline solutions. A part of the resulting atomic hydrogen is recombined to molecular hydrogen and escapes. The remaining hydrogen can be absorbed by the metal due to its 
small size $[7,8]$. The amount of hydrogen absorbed is influenced by the $\mathrm{pH}$-value of the solution, the temperature and catalytic elements [9]. The use of inhibitors that counteract metal dissolution, for example, can result in increased hydrogen absorption $[9,10]$.

The corrosion probability for different metal electrolyte systems can be estimated by potential-pH-diagrams, so-called Pourbaix diagrams. Figure 1 shows the equilibrium diagram for iron from a thermodynamic point of view. Reactions with other elements are not taken into account.

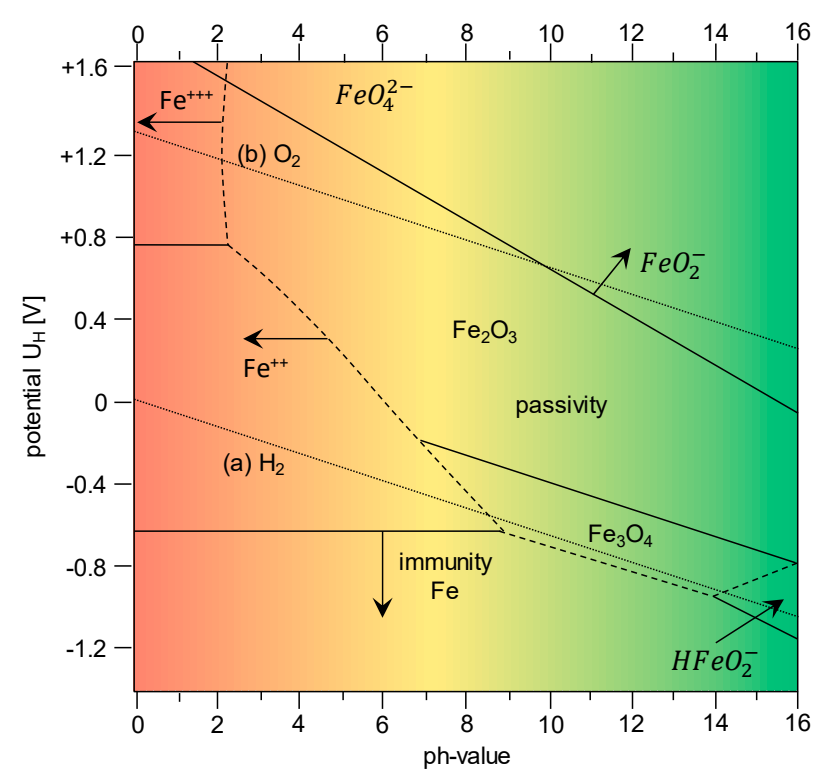

Figure 1. Potential pH diagram for iron based on [10,11].

Depending on the $\mathrm{pH}$-value and the potential, the respective stability ranges of the individual bonds can be derived. The metal is stable in the area of "immunity" and there is no corrosion attack (cathodic corrosion protection). In the other zones the material can corrode [10-12]. An exception is the area of passivity, where firmly adhering, hardly soluble oxides or hydroxides can form a dense barrier layer and, thus, prevent further corrosion. It is not possible to determine from the diagrams whether a passive layer has a protective effect [10-13]. Figure 1 shows that iron is decomposed in acidic media to form metal ions. Strong alkaline solutions cause corrosion by releasing metal oxide ions. The dotted lines (a) and (b) symbolize the existential area of the water. In between the two straight lines, the water molecule is stable. Potentials above (b) lead to dissociation of the water under oxygen development. Below (a), hydrogen is formed. If only the immunity range of iron is considered, it becomes clear that iron and water cannot coexist. A potential reduction in the insensitive range leads to a decomposition of the water by hydrogen formation. If the voltage is increased, the metal dissolves. Only the $\mathrm{Fe}_{2} \mathrm{O}_{3}$ and $\mathrm{Fe}_{3} \mathrm{O}_{4}$ molecules in the passive range can coexist with water [10]. For loading the steel as well as for referencing the permeation measurements, the following approaches were, therefore, chosen in the tests:

1. Influence of the $\mathrm{pH}$-value (passive layer and corrosion) on hydrogen absorption and hydrogen diffusion;

2. Influence of sample thickness (ratio of substrate to passive layer); and

3. Influence of the surface condition (surface roughness).

\subsection{Hydrogen Transport}

Thermal Desorption Analysis (TDA): No matter how the hydrogen is absorbed, due to its small size, it can migrate freely in the metal lattice by interstitial diffusion. The direction of mass transport is determined by the concentration, stress, temperature and potential gradients [8]. Its mobility is 
expressed by the substance- and temperature-dependent diffusion coefficient $D$, which is given in Equation (1). The function is described by the material-specific diffusion constant $D_{0}$ and an exponential part. The variables symbolize the activation energy $E_{a}$, the universal gas constant $R$, and the absolute temperature $T$ :

$$
\mathrm{D}=D_{0} \cdot \exp \left(-\frac{E_{a}}{R \cdot T}\right)
$$

The activation energy can be determined by applying thermal desorption analysis using different heating rates $q$ with Equation (2):

$$
\frac{d\left[\ln \left(\frac{q}{T_{\max }^{2}}\right)\right]}{d\left[\frac{1}{T_{\max }}\right]}=-\frac{E_{a}}{R}
$$

The temperatures Tmax at which the highest desorption rates occur are determined. Depending on the sample geometry, the diffusion constant can then be calculated using the material thickness $\mathrm{d}$ with Equation (3). The variable $\mathrm{u}_{1}$ represents the first zero of the Bessel function [14-16]:

$$
\begin{array}{cc}
\text { thin sheet geometry } & \text { cylinder geometry } \\
\mathrm{D}_{0}=\frac{q \mathrm{E}_{\mathrm{a}} \mathrm{d}^{2}}{\pi^{2} \mathrm{RT}_{\max }^{2} \cdot \mathrm{e}^{\left(-\frac{\mathrm{E}_{\mathrm{a}}}{R T_{\max }}\right)}} & \mathrm{D}_{0}=\frac{q \mathrm{E}_{\mathrm{a}} \mathrm{a}^{2}}{\mathrm{u}_{1}^{2} \mathrm{RT}_{\max }^{2} \cdot \mathrm{e}^{\left(-\frac{\mathrm{E}_{\mathrm{a}}}{R T_{\max }}\right)}}
\end{array}
$$

Permeation measurements: The Devanathan and Stachursky method has been established in practice for the electrochemical determination of the diffusion rate of hydrogen. It is a two-chamber measuring cell or double cell filled with electrolytes (see Figure 2). One side is cathodically polarized and used for hydrogen production. The other side is anodized and oxidizes the permeating hydrogen. The chambers are separated from the investigated material. On the cathodic side, hydrogen is produced according to the HER mechanism. The hydrogen migrates through the sample and exits the analysis cell. It is oxidized. Oxidation of the hydrogen produces a current. This is measured and provides information about the hydrogen transport behaviour of the material. Two important conditions apply to the process. On the one hand, the hydrogen concentration must be constant on the loading side and zero on the analysis side [17]. A constant hydrogen absorption can easily be achieved under unchanging test conditions. The standard [18] recommends an electrolyte sample area ratio of at least 20:1 $\left(\mathrm{mL}: \mathrm{cm}^{2}\right)$ so that the composition of the solution or consumption has no influence on the result during the measurement. The zero concentration on the analysis side is usually ensured in practice with a $0.1 \mathrm{~mol} / \mathrm{L} \mathrm{NaOH}$ solution under the assumption that the high $\mathrm{OH}^{-}$ion concentration leads to an immediate oxidation of the hydrogen [17].

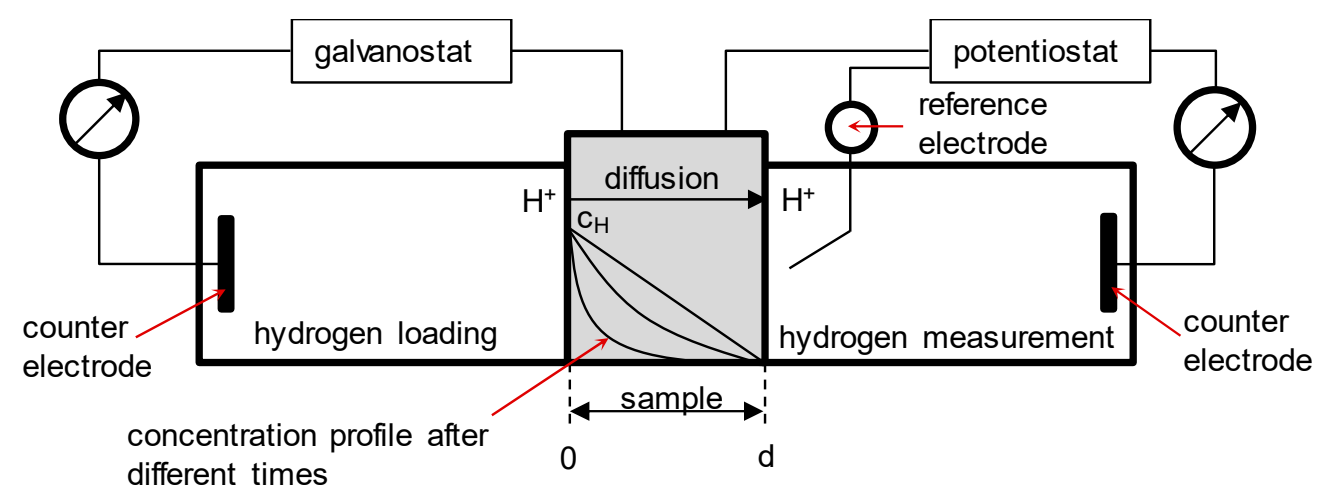

Figure 2. Schematic representation of a hydrogen permeation test based on [13].

For recording the permeation current, a constant potential is applied to the oxidation side. First, a passive current (background current, see Figure 3) is generated, which has to be subtracted from the permeation current. The hydrogen penetrating over time generates an additional current by oxidation (permeation curve) $[17,18]$. According to Faraday's laws, the electric current corresponds to 
the material flow. Figure 3 shows a schematic permeation process. The hydrogen diffusion coefficient of the investigated material can be determined on the basis of the measurement signal. There are several analysis methods for the evaluation. Within the scope of this work, the focus is on the breakthrough-time method, the time-lag method and the turning point method. The distinctive points for the determination of the diffusion coefficients according to the respective method are shown in Figure 3 [17].

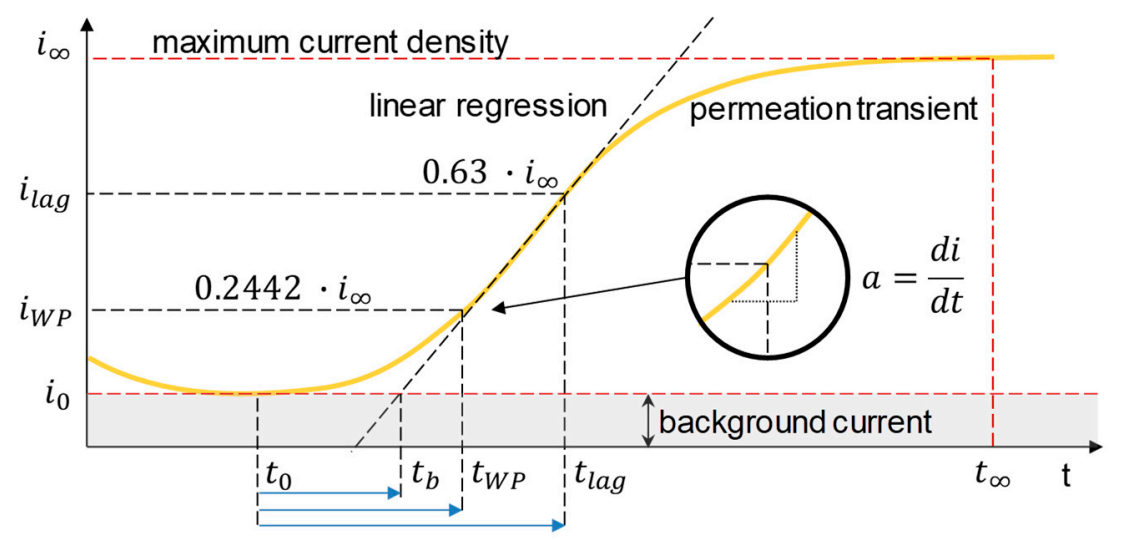

Figure 3. Schematic representation of an idealized permeation curve with the significant points.

To determine the diffusion coefficient according to the breakthrough-time method, the time $t_{b}$ is determined via a regression of the linear component of the permeation current. The point of intersection of the extrapolation with the abscissa, after deduction of the background current, corresponds to $t_{b}$ [18]. The times $t_{W P}$ and $t_{\text {lag }}$ are read at the characteristic points, $24.42 \%$ and $63 \%$, respectively, of the maximum current density (see Figure 3). The diffusion coefficient can be determined using the following equations, taking the diffusion path covered (sample thickness $\mathrm{d}$ ) of the hydrogen and the respective times into account. For the turning point method, the gradient at this point $\left(t_{W P}, i_{W P}\right)$ must also be determined $[17,18]$ :

$$
\begin{gathered}
\text { Breakthrough-Time } \\
\quad D \approx \frac{d^{2}}{15.3 \cdot t_{b}}
\end{gathered}
$$

Time-Lag-Method

$$
D \approx \frac{d^{2}}{6 \cdot t_{\text {lag }}}
$$

$$
\begin{aligned}
& \text { Turning-Point-Method } \\
& D \approx \frac{0.04124 \cdot d^{2}}{0.2442 \cdot i_{\infty}} \cdot a \text { with } a=\frac{d i}{d t}
\end{aligned}
$$

Diffusion equations: The determination of the diffusion coefficient allows a local and temporal description of the hydrogen movement in the metal lattice by applying the following diffusion equation:

$$
c(x, t)=c_{R}+\frac{4\left(c_{0}-c_{R}\right)}{\pi} \cdot \sum_{n=0}^{\infty} \frac{1}{(2 n+1)} \cdot \sin \left(\frac{(2 n+1) \pi}{d} x\right) \cdot \exp \left(-\frac{(2 n+1)^{2} \cdot \pi^{2}}{d^{2}} D t\right)
$$

The equation is applicable under the following restrictions:

1. Diffusion occurs only in the thickness direction, therefore the equations are only valid for sheets whose thickness is small compared to the remaining dimensions;

2. The mean hydrogen concentration in the workpiece at the beginning is equal to the initial concentration ( $\mathrm{c}=c_{0}$ for $0 \leq x \leq d$ for $t=0$ );

3. The hydrogen concentration in the sample at time $t=0$ is uniformly distributed; and

4. The hydrogen concentration on the metal surface is constant $\left(c_{R}=\right.$ constant for $x=0$ and $x=d$ for $t>0$ ). 
A list of the variables can be found in Table 1.

Table 1. List of variables for the diffusion equations.

\begin{tabular}{cc}
\hline Symbol & Description \\
\hline$c(x, t)$ & Hydrogen at location " $x$ " at time " $t$ " \\
$\bar{c}(t)$ & Average hydrogen concentration at time " $t$ " \\
$c_{R}$ & Hydrogen boundary concentration \\
$c_{0}$ & Initial hydrogen concentration \\
$X$ & Position/location of hydrogen in the workpiece \\
$N$ & Running number of the infinite sum \\
$D$ & Material thickness \\
$D$ & Diffusion coefficient \\
\hline
\end{tabular}

The integration of the initial equations according to $x$ in the limits $0-\mathrm{d}$ allows the calculation of the average hydrogen concentration as a function of time. With sufficiently long times, the function can be simplified by removing the Fourier series:

$$
\text { Thin sheet: } \quad \bar{c}(t)=c_{R}+\frac{8\left(c_{0}-c_{R}\right)}{\pi^{2}} \sum_{n=0}^{\infty} \frac{1}{(2 n+1)^{2}} \cdot \exp \left(-\frac{(2 n+1)^{2} \pi^{2}}{d^{2}} D t\right)
$$

The equations allow an estimation of the desorption time as a function of temperature and material thickness [16,19].

\section{Materials and Methods}

Objective of the study: The aim of the investigation is to determine the diffusion rate for hydrogen in the boron-manganese steels 22MnB5 and 37MnB4 by comparing different methods and influencing variables. Permeation measurements and thermal desorption measurements are carried out with constant heating rate and isothermal temperature control. The special feature of this procedure is the application of different measuring methods as well as an adjustment of the diffusion velocities among each other. A high quality of the determined values is aimed at.

The diffusion velocity allows conclusions to be drawn about the hydrogen transport behaviour in components. Thus, the hydrogen distribution in the material can be computed. In addition, desorption times can be calculated under various boundary conditions such as temperature, time and material thickness. The calculated and measured effusion times are compared and the diffusion coefficients are, therefore, controlled.

From these calculations, critical time periods can be determined in which hydrogen-assisted crack formation can occur. Furthermore, processes such as hydrogen annealing can be adjusted very precisely and energy-efficiently.

By applying these methods to coating systems, barrier effects can be identified. The diffusion inhibition of hydrogen in coating concepts can be both positive and negative. On the one hand, hydrogen is prevented from penetrating by a barrier and on the other hand from desorption if $\mathrm{H}$-absorption has taken place before the coating process. Knowledge of the diffusion velocity in the material system is, therefore, of decisive importance for the safe use of these steels.

\subsection{Material Characterization and Sample Preparation}

For the tests, sheets of 22MnB5 with an AlSi coating (AS150) were hardened in the laboratory. The blanks were first heated in a furnace to $930{ }^{\circ} \mathrm{C}$ for $6 \mathrm{~min}$ to convert the ferritic-perlitic initial structure into an austenitic one. Following the heat treatment, the workpieces were rapidly cooled in a press tool, converting the austenite into martensite. The finished flat samples had a dimension of $60 \mathrm{~mm} \times 20 \mathrm{~mm} \times 1.5 \mathrm{~mm}$ and were stored in a cryogenic container filled with liquid nitrogen. Cutting was carried out by laser beam cutting before austenitisation. In the last step, the coating was 
removed by mechanical grinding with a surface grinding machine. The sample thickness was still $1.3 \mathrm{~mm}$ after the process. The procedure had several advantages. There was no scale or decarburization due to the heat treatment. In addition, the AS150 coating led to hydrogen enrichment of the samples already during austenitisation (see Figure 4). The variation of the furnace dwell time took place at a temperature of $930^{\circ} \mathrm{C}$, the variation of the temperature at a furnace dwell time of $6 \mathrm{~min}$.

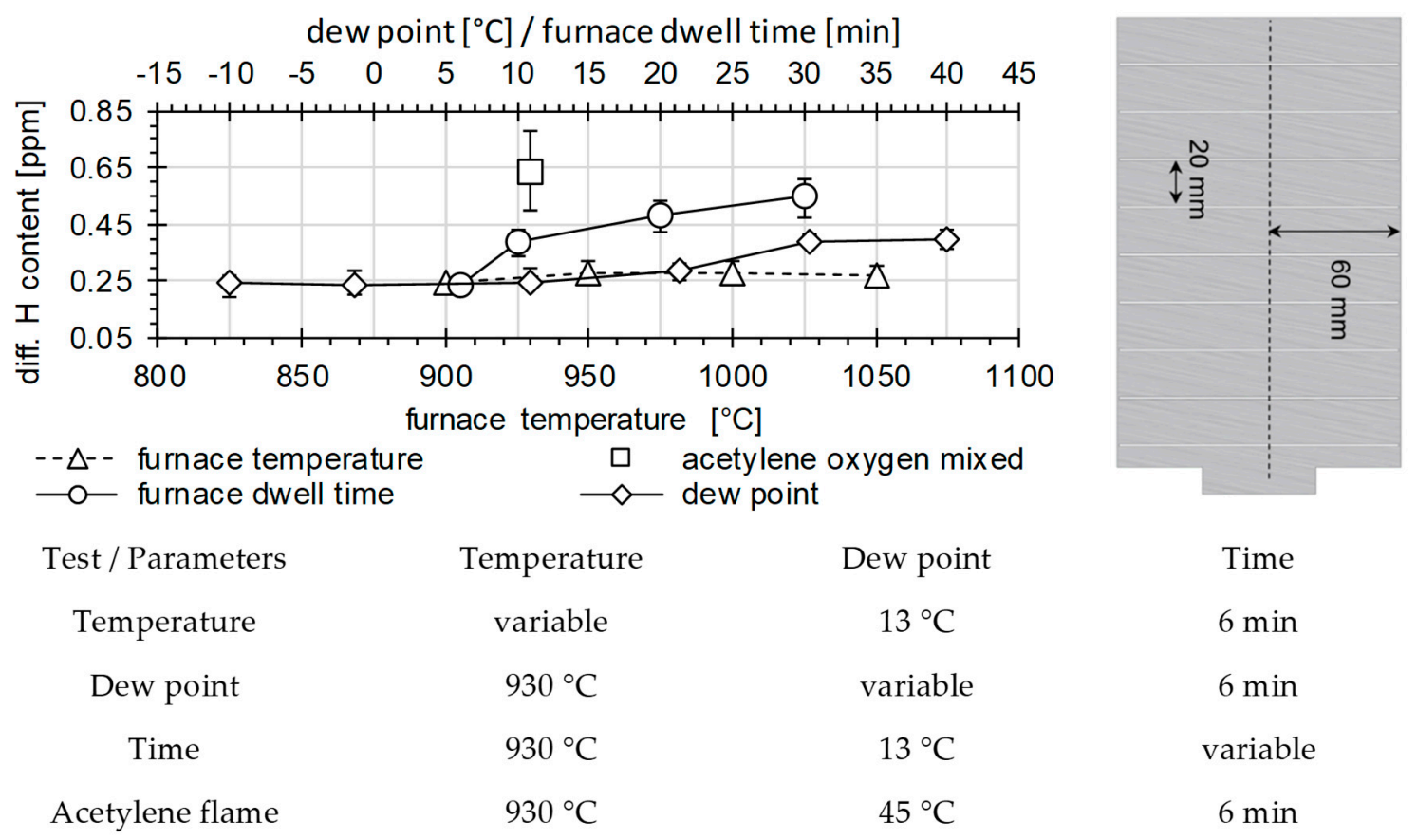

Figure 4. Hydrogen absorption during austenitisation under different conditions and sample geometry.

The quenched and tempered material 37MnB4 (without coating) was also included as a reference material in the investigations. It was austenitized at $900{ }^{\circ} \mathrm{C}(10 \mathrm{~min})$ under a nitrogen atmosphere and then quenched in water. Press hardening was not possible due to a round sample geometry. After hardening, the material was tempered at $315^{\circ} \mathrm{C}$ for 15 minutes. Both materials used had a hardness of around $480 \mathrm{HV}$ after quenching and tempering. The measured chemical composition of the steels is summarized in Table 2.

Table 2. Measured chemical composition in \% by weight of $22 \mathrm{MnB} 5$ and $37 \mathrm{MnB} 4, \mathrm{~min} / \mathrm{max}$ values taken from [20].

\begin{tabular}{cccccccccc}
\hline 22MnB5 & $\mathbf{C}$ & $\mathbf{S i}$ & $\mathbf{M n}$ & $\mathbf{P}$ & $\mathbf{S}$ & $\mathbf{C r}$ & $\mathbf{A l}$ & $\mathbf{T i}$ & $\mathbf{B}$ \\
\hline min. & 0.20 & 0.20 & 1.10 & - & - & 0.15 & 0.020 & 0.020 & 0.0008 \\
actual values & 0.23 & 0.24 & 1.21 & 0.012 & 0.002 & 0.22 & 0.035 & 0.037 & 0.0030 \\
max. & 0.25 & 0.40 & 1.40 & 0.025 & 0.010 & 0.35 & 0.060 & 0.050 & 0.0050 \\
37MnB4 & & & & & & & & & \\
min. & 0.34 & - & 0.80 & - & - & 0.15 & 0.02 & 0.02 & 0.001 \\
actual values & 0.36 & 0.06 & 0.77 & 0.011 & 0.007 & 0.26 & 0.05 & 0.04 & 0.004 \\
max. & 0.40 & 0.40 & 1.10 & 0.025 & 0.015 & 0.35 & 0.06 & 0.05 & 0.005 \\
\hline
\end{tabular}

Table 3 compares the sample geometry used.

Table 3. Dimensions of the sample.

\begin{tabular}{ccc}
\hline Material & Permeation & Thermal Desorption Analysis \\
\hline $22 \mathrm{MnB5}$ & $\varnothing 25 \mathrm{~mm}, d=1-1.2 \mathrm{~mm}$ & $60 \mathrm{~mm} \times 20 \mathrm{~mm} \times 1.3 \mathrm{~mm}$ \\
$37 \mathrm{MnB} 4$ & $\varnothing 25 \mathrm{~mm}, d=1-1.2 \mathrm{~mm}$ & $\varnothing 4.5 \mathrm{~mm}, 1=100-120 \mathrm{~mm}$ \\
\hline
\end{tabular}




\subsection{Permeation Measurements}

To determine the diffusion coefficients and their dependence on different boundary conditions such as pH-value, sample surface and sample thickness, experiments were carried out with an electrochemical double cell. A tapered bore improved the removal of the formed hydrogen bubbles. The through-hole at the interface between electrolyte and sample had a diameter of $10 \mathrm{~mm}$. A sealing ring on each side as well as the screw connection of the two cells prevented leakage of the solution or the formation of a leakage current. The chambers had a capacity of about $0.7 \mathrm{~L}$, which means that the solution is less sensitive to impurities caused by dissolved substances, even during longer experiments (see Figure 5).

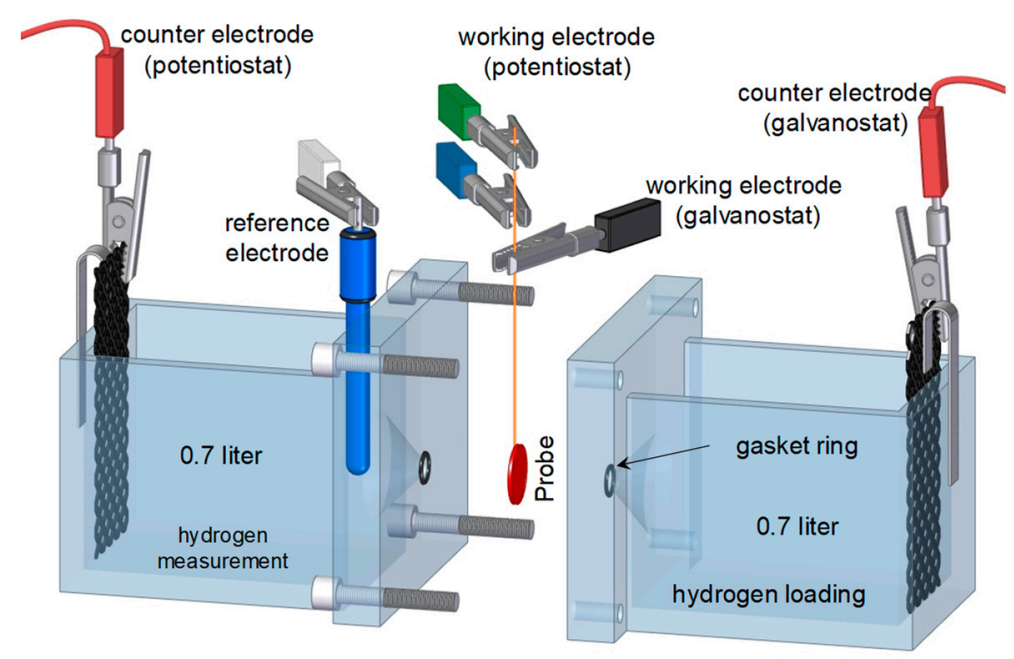

Figure 5. Structure of the double cell for permeation measurements.

The loading side was operated galvanostatically $\left(100 \mathrm{~mA} / \mathrm{dm}^{2}\right)$ and the oxidation side potentiostatically. The circuit of the respective cell was closed with a counter electrode made of titanium oxide mixture. The voltage in the analysis cell was adjusted with an $\mathrm{Ag} / \mathrm{AgCl}$ reference electrode and was a constant $500 \mathrm{mV}$. A $0.1 \mathrm{~mol} / \mathrm{L} \mathrm{NaOH}$ solution was used to ensure a high oxidation of the penetrating hydrogen. In order to achieve a faster reduction of the corrosion current, the samples were ground on the analysis side (grain size P80).

First, the conditions of hydrogen accumulation were characterized. The samples were cathodically polarized and the galvanostatically controlled circuit was closed with two opposing titanium-titanium oxide anodes. The solution-sample-surface ratio was at least $2 \mathrm{~L}$ per $\mathrm{dm}^{2}$ according to [18]. The influence of the $\mathrm{pH}$-value of a sulphuric acid, a sodium hydroxide solution (molarity: $10^{-6}$ to $10^{-1} \mathrm{~mol} / \mathrm{L}$ ) and distilled water on the hydrogen absorption was investigated. The solution was enriched with $1 \mathrm{~g} / \mathrm{L}$ thiourea $\left(\mathrm{CH}_{4} \mathrm{~N}_{2} \mathrm{~S}\right)$ as promoter. In addition, $1 \mathrm{~g} / \mathrm{L} \mathrm{NaCl}$ was added as conductive salt at low molarities due to the poor conductivity. Hydrogen enrichment was carried out at $100 \mathrm{~mA} / \mathrm{dm}^{2}$ for one hour. Subsequently, the effect of the current density was examined. It was varied from $1 \mathrm{~mA} / \mathrm{dm}^{2}$ to $1000 \mathrm{~mA} / \mathrm{dm}^{2}$. As solution a $10 \mathrm{mmol} / \mathrm{L} \mathrm{NaOH}+1 \mathrm{~g} / \mathrm{L} \mathrm{CH}_{4} \mathrm{~N}_{2} \mathrm{~S}$ was used. The surface of the samples was cleaned of impurities before loading with a $20 \%$ hydrochloric acid $\left(+5 \mathrm{~g} / \mathrm{L} \mathrm{C}_{6} \mathrm{H}_{12} \mathrm{~N}_{4}\right.$ ). The loading time was fixed at one hour. After loading, the samples were stored in liquid nitrogen (max. one week). Hydrogen was measured at $200{ }^{\circ} \mathrm{C}$ by thermal desorption analysis (TDA). Before the measurement, the samples were thawed, cleaned in acetone and weighed.

The permeation measurements were then carried out. Possible parameters that have a direct influence on the permeation measurement were investigated. Here, the sample surface, the sample thickness and the $\mathrm{pH}$-value can be mentioned. 


\subsection{Thermal Desorption Analysis}

Hydrogen quantification was performed with a G8 Galileo from Bruker (Bruker, Billerica, MA, USA), coupled to a quadrupole mass spectrometer (ESD 100) (Process Instruments, Bremen, Germany) (see Figure 6). The measuring instrument works according to the carrier hot gas extraction principle. High-purity nitrogen (N 5.0) was used for the hydrogen analysis. The hydrogen transport behaviour was determined by heating with constant heating rates in a nitrogen-purged infrared furnace. The set temperature was monitored internally in the furnace and with an external thermocouple. The samples stored in liquid nitrogen were cleaned in an ultrasonic bath (filled with acetone) for one minute and then weighed. An empirical test of the diffusion behaviour was carried out by isothermal measurements. Comparative observations were carried out on the basis of the analyses and the previously determined activation energy and pre-exponential diffusion coefficients using the diffusion equations presented in the introduction. The test conditions used are listed in Table 4.

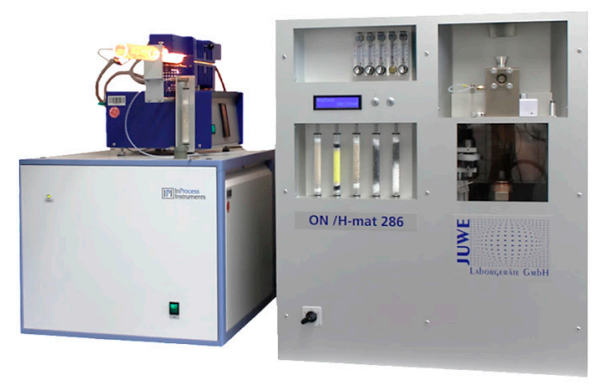

Figure 6. G8 Galileo, coupled with a quadrupole mass spectrometer.

Table 4. Measurement parameters of the TDA for the characterization of hydrogen uptake, the determination of $E_{a}$ and $D_{0}$ and the empirical verification of the desorption time.

\begin{tabular}{ccc}
\hline & $E_{a} / D_{0}$ & Desorption Time \\
\hline Analysis temperature and & $0.2 ; 0.4 ; 0.6 ; 0.8 ; 1.0{ }^{\circ} \mathrm{C} / \mathrm{s}(\Delta \mathrm{T}$ from & $150-300{ }^{\circ} \mathrm{C}$ for the empirical \\
heating rate & 50 to $\left.900{ }^{\circ} \mathrm{C}\right)$ & Validation of desorption time \\
Analysis time & $\Delta \mathrm{T} / \mathrm{q}$ & $20-30 \mathrm{~min}$ \\
\hline
\end{tabular}

\section{Results and Discussion}

\subsection{Determination of H Diffusion by Permeation Measurement}

Charging parameters: Without the promoter, which inhibits the recombination of hydrogen, there was no significant hydrogen absorption. The same effect was observed with sulphuric acids of different molarity (see Figure 7). In contrast to the acids, the bases exhibited poor electrical conductivity. It was shown that from a molarity of $1 \mathrm{mmol} / \mathrm{L} \mathrm{NaOH}$ and $0.1 \mathrm{mmol} / \mathrm{L} \mathrm{H}_{2} \mathrm{SO}_{4}$ the potential limit of $20 \mathrm{~V}$ of the galvanostat was exceeded. The solutions were mixed with $1 \mathrm{~g} / \mathrm{L} \mathrm{NaCl}$ to improve conductivity. It was found that $\mathrm{NaCl}$ has no influence on hydrogen absorption.

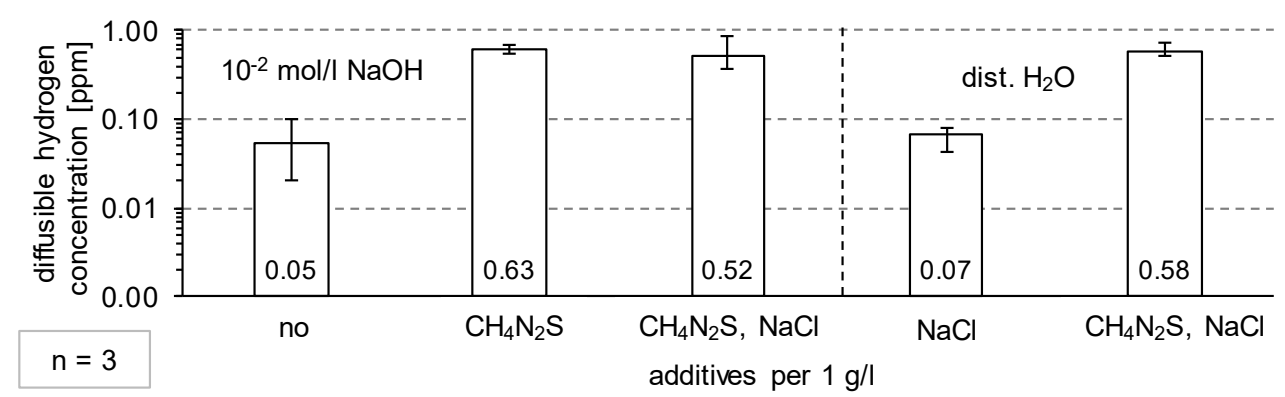

Figure 7. Influence of $\mathrm{NaCl}$ and $\mathrm{CH}_{4} \mathrm{~N}_{2} \mathrm{~S}$ content on hydrogen absorption at a current density of $100 \mathrm{~mA} / \mathrm{dm}^{2}$. 
Figure 8 describes the hydrogen uptake under the influence of different $\mathrm{pH}$-values. It could be observed that hydrogen absorption is not further influenced from a pH-value greater than 3 . It can be assumed that additional hydrogen is produced by corrosion (metal dissolution) at $\mathrm{pH}$-values less than or equal to 3 . Higher values cause passivation by the formation of a barrier layer.

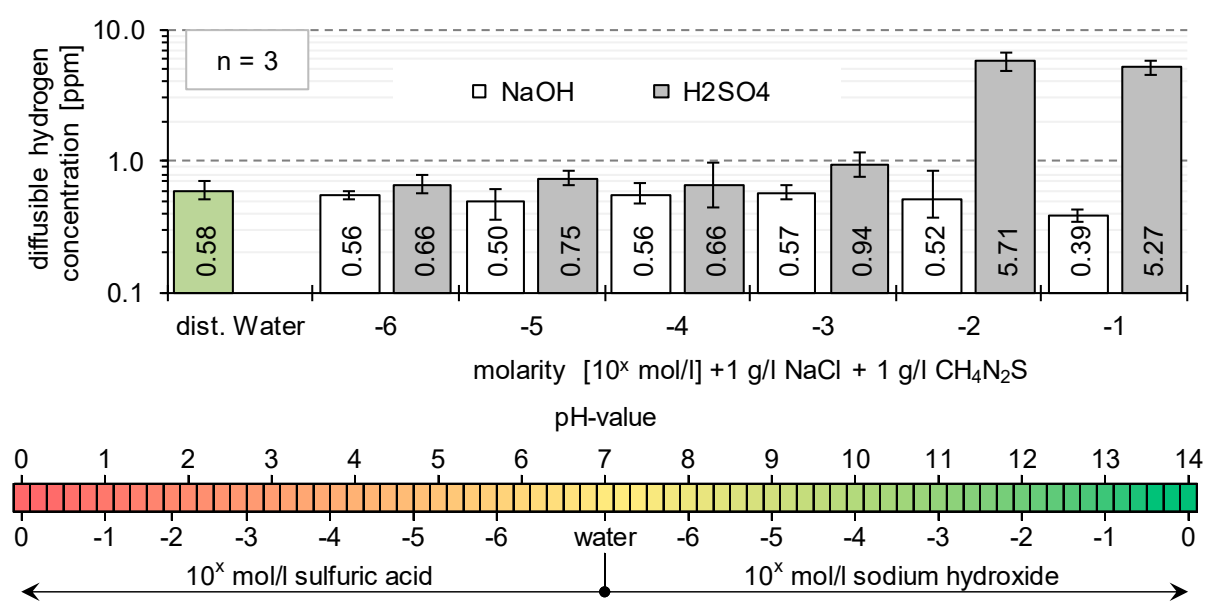

Figure 8. Impact of the $\mathrm{pH}$ value on the hydrogen concentration (above) at a current density of $100 \mathrm{~mA} / \mathrm{dm}^{2}$ and (below) the calculated $\mathrm{pH}$-value from the respective molarity of the solution.

The current density has a considerable influence on the hydrogen absorption (see Figure 9). A current density of $1 \mathrm{~mA} / \mathrm{dm}^{2}$ did not lead to hydrogen absorption. With higher currents a steadily increasing hydrogen absorption could be observed, but also an increased bubble formation. A strong formation of bubbles during the permeation measurements could lead to falsification of the results, as they occupy the workpiece surface and thus influence the resulting current density. The investigations were carried out with a $10 \mathrm{mmol} / \mathrm{L} \mathrm{NaOH}$ solution $\left(1 \mathrm{~g} / \mathrm{L} \mathrm{NaCl}\right.$ and $\mathrm{CH}_{4} \mathrm{~N}_{2} \mathrm{~S}$ for each). Since there was no direct correlation between $\mathrm{pH}$-values greater than 3 and hydrogen absorption (see Figure 9) it was assumed that the investigated current densities were representative for all $\mathrm{NaOH}$ polarities up to $10^{-4} \mathrm{~mol} / \mathrm{L} \mathrm{H}_{2} \mathrm{SO}_{4}$.

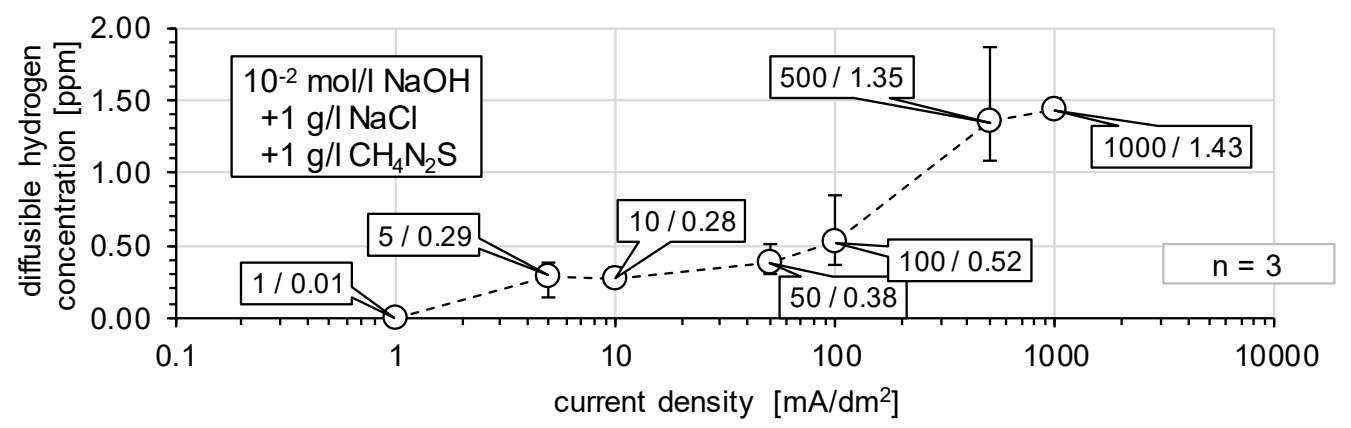

Figure 9. Influence of current density on hydrogen absorption.

Influence of the $\mathrm{pH}$-value: Figure 10 shows the measured oxidation currents for 1-100 mmol/L $\mathrm{NaOH}$ and $\mathrm{H}_{2} \mathrm{SO}_{4}$ after deduction of the corrosion current. The bases used led to almost identical curves. From a molarity of $1 \mathrm{mmol} / \mathrm{L} \mathrm{H}_{2} \mathrm{SO}_{4}$ the measured oxidation currents increased steadily. A concentration of $10 \mathrm{mmol} / \mathrm{L}$ and $100 \mathrm{mmol} / \mathrm{L} \mathrm{H}_{2} \mathrm{SO}_{4}$ caused a very steep increase of the measurement curves. The sudden increase in hydrogen absorption from a sulphuric acid molarity of $10 \mathrm{mmol} / \mathrm{L}$ could already be determined during the loading tests. During the standardization of the data, only small differences were found in the courses. The right part of Figure 10 shows the sample after the permeation tests. The measuring surface was free of corrosion products. Only an outer corrosion ring 
was formed. It can be assumed that the ring was caused by contact corrosion. The ring appeared in all investigations and had no measurable influence.

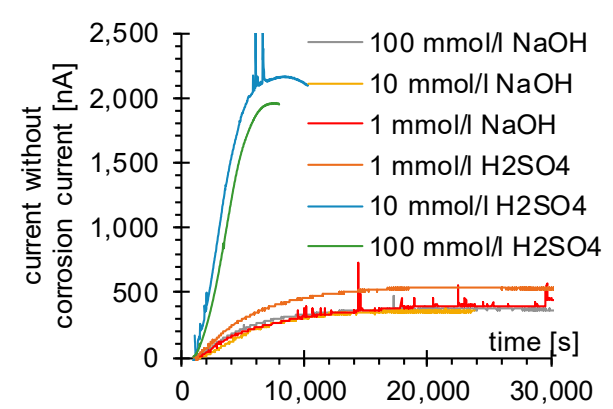

(a)

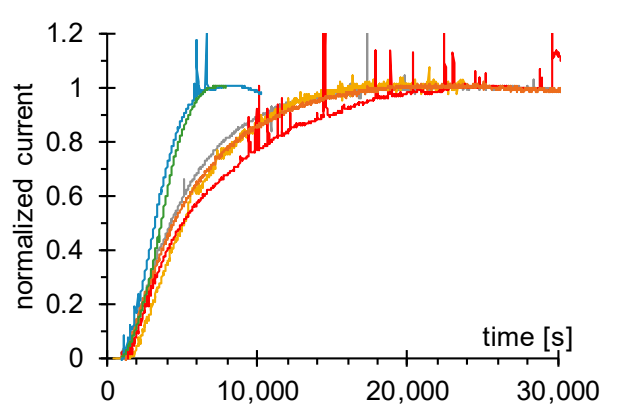

(b)

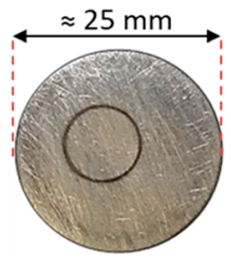

(c)

Figure 10. (a) Comparison of the measured currents, adjusted for corrosion current, at different $\mathrm{pH}$-values on the loading side for the press-hardened 22MnB5, (b) normalized current of (a) and (c) sample after measurement.

Figure 11 summarizes the results of the investigations with $\mathrm{NaOH}$ and $\mathrm{H}_{2} \mathrm{SO}_{4}$ of different polarities as loading solution. All electrolytes were mixed with $1 \mathrm{~g} / \mathrm{L} \mathrm{CH}_{4} \mathrm{~N}_{2} \mathrm{~S}$, the alkaline ones additionally with $1 \mathrm{~g} / \mathrm{L} \mathrm{NaCl}$. A slight increase of the diffusion rate could be observed with increasing reduction of the $\mathrm{pH}$-value. The cause is assumed to be the formation of a passive layer at higher $\mathrm{pH}$-values. Acid solutions, on the other hand, lead to a dissolution of the oxide layer, which is presumably diffusion-inhibiting. However, the low influence of the $\mathrm{pH}$-value and the associated passivation can also be attributed to the sample thickness $(\approx 1 \mathrm{~mm})$. The diffusion-inhibiting effect of the passive layer is almost negligible due to the thickness ratios between substrate and oxide layer. On average, identical diffusion coefficients could be determined for both quenched and tempered steels $\left(\approx 4 \times 10^{-11} \mathrm{~m}^{2} / \mathrm{s}\right.$ at room temperature).

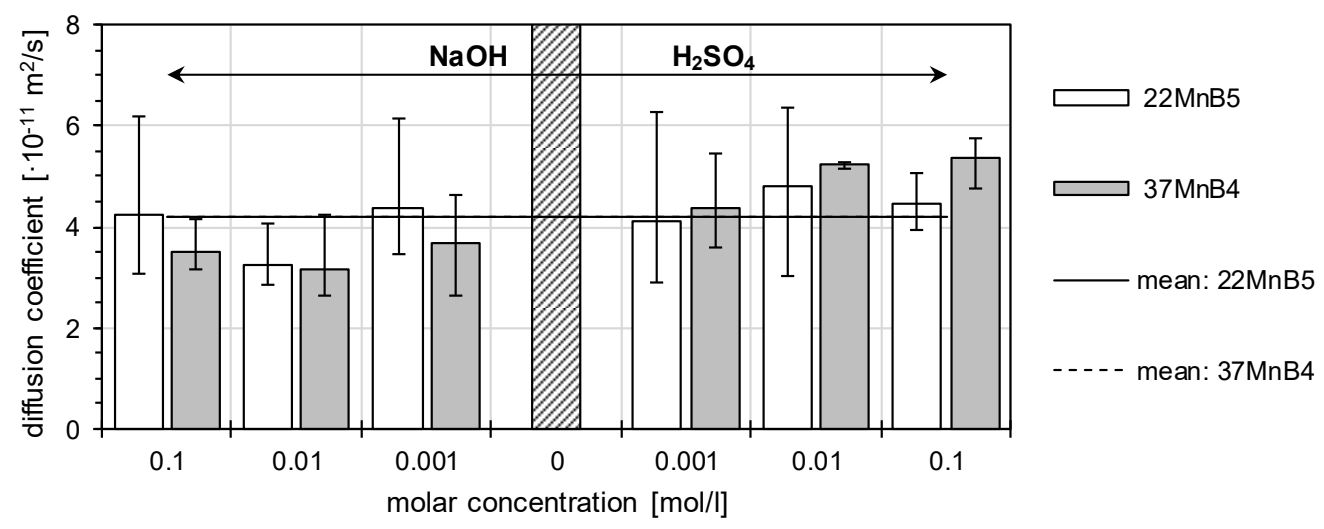

Figure 11. Comparison of the determined diffusion coefficients (mean value of $t_{b}, t_{\text {lag }}$ and $t_{W P}$ ) for the quenched and tempered steels 22MnB5 and 37MnB4 for alkaline and acid solutions at a current density of $100 \mathrm{~mA} / \mathrm{dm}^{2}$.

Influence of sample thickness: The influence of possible oxide layers or passive layers was determined. Barrier and cover layers on the metal can inhibit diffusion. The change of the material thickness with an assumed constant barrier layer should clarify the influence. An increase of the diffusion velocity from a material thickness of $1.4 \mathrm{~mm}$ could be observed as well as a growing discrepancy between the ferritic starting material and the martensitic hardened steel. It can be assumed that the absorption time has an influence on the measured diffusion time if the thickness is too low. The effect is further enhanced if the material to be investigated (such as the ferritic material) has a 
high H-diffusion rate. In martensitic microstructures with a lower diffusion rate, the influence is already significantly reduced. In addition, the influence of the $\mathrm{pH}$-value becomes more pronounced (see Figure 12).

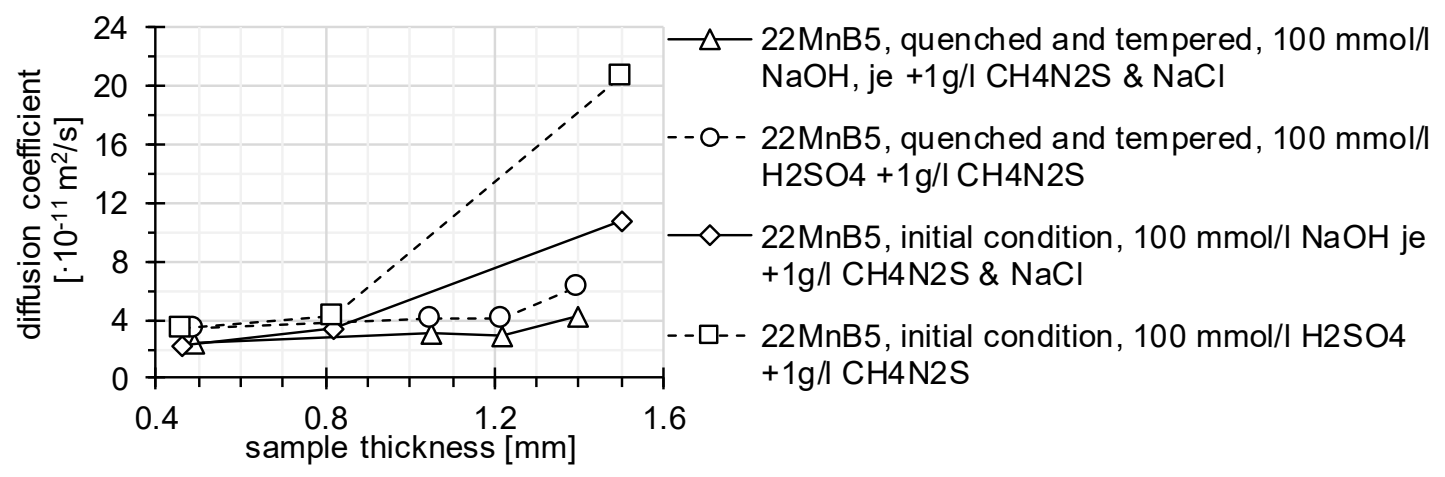

Figure 12. Impact of sample thickness on permeation measurement 22MnB5 in untempered and tempered condition.

In [21] the same effect could be observed. The authors tested the influence of a $0.5-2 \mathrm{~mm}$ thick sample. With increasing membrane thickness the measured permeation current density decreases. In contrast, the diffusion coefficients determined by the time-lag method were increased. The diffusion coefficient increased from $1.10 \times 10^{-11} \mathrm{~m}^{2} / \mathrm{s}(0.5 \mathrm{~mm})$ to $3.49 \times 10^{-11} \mathrm{~m}^{2} / \mathrm{s}(2 \mathrm{~mm})$ for pure iron. The authors held mechanical polishing responsible, which led to a change in the microstructure and, thus, to hardening [21]. The effect explains the significant difference in the investigations carried out here. In the initial state, strain hardening is more pronounced than in the quenched and tempered state due to the lower strength. An examination was carried out by varying the processing of the sample surface on hardened 22MnB5 thin sheets.

Influence of surface condition: 22MnB5 fine bleach with different grain sizes (P800 and P80) was ground and prepared by compressed air blasting with solid $\mathrm{Al}_{2} \mathrm{O}_{3}$ granulate (see Figure 13). The surface with a P800 grain was produced by stepwise polishing. The surfaces were processed on the loading side as well as on the analysis side. By using an acid and a lye the $\mathrm{pH}$-value should be excluded. Compressed air blasting led to the lowest diffusion velocities. It can be assumed that this process produces the highest surface hardenings. Grinding with different grain sizes, on the other hand, does not seem to have any discernible influence.

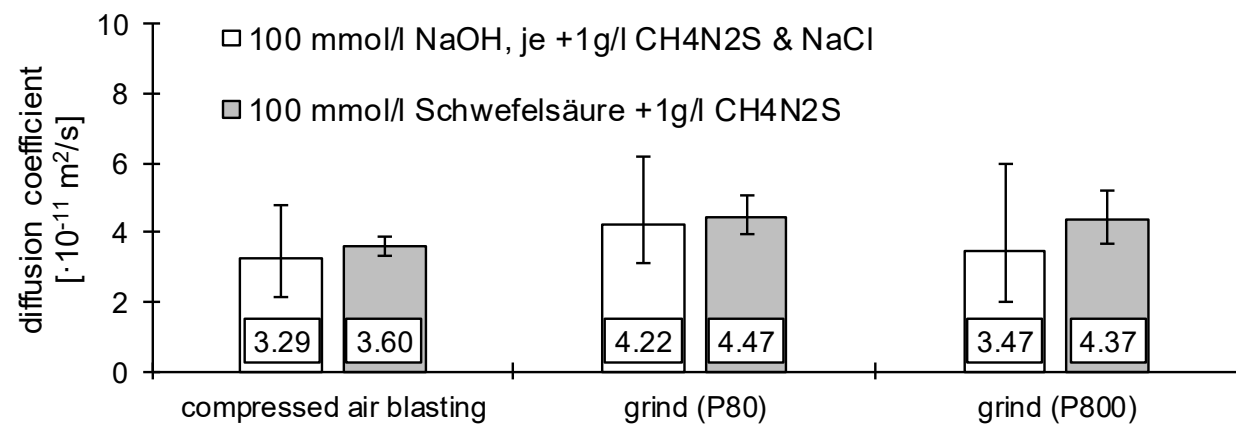

Figure 13. Impact of the surface quality of the samples on the permeation measurement (22MnB5-press-hardened condition).

\subsection{Determination of H Diffusion by Thermal Desorption Analysis}

Constant heating rate (temperature ramp): Figure 14 (left) shows various desorption curves for the $22 \mathrm{MnB} 5$ and its coating concepts. For a more detailed description of the coating concepts, please refer to the publications [22]. All curves were subject to the same temperature regime. It can be seen that the coatings shift the signal maxima to higher temperatures. From this it can be concluded that the 
zinc-based and even more so the aluminium-based coating prevents hydrogen diffusion and therefore also inhibits desorption. In the right part of Figure 14, the temperatures of the signal maxima and the corresponding heating rates are entered according to Equation (2) and their increase is determined by a linear regression. The activation energy was determined by multiplying the increase by the negative of the universal gas constant.
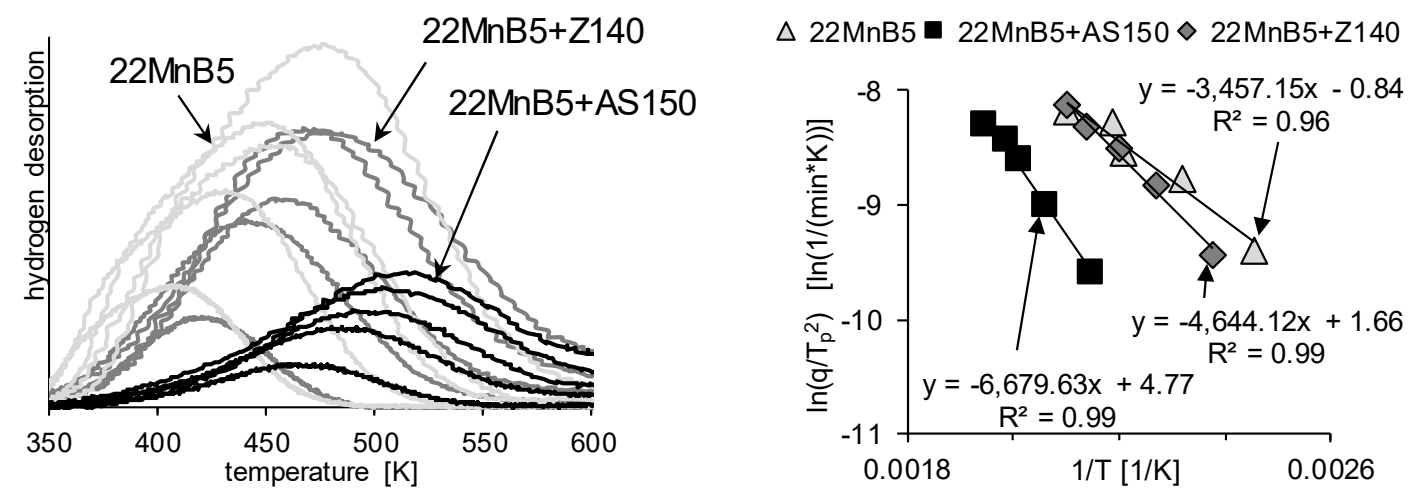

Figure 14. Thermal desorption analysis on $22 \mathrm{MnB5}$ sheets with different coating concepts and varying heating rates (left), representation of the results according to Equation (2) (right).

The diffusion constant was then calculated, depending on the sample geometry, using the material thickness $\mathrm{d}$ or radius a with Equation (3). The following values result for the quenched and tempered steels 37MnB4 and 22MnB5 and their coating concepts (see Table 5). The listed diffusion coefficients were calculated with Equation (1) at a temperature of $22{ }^{\circ} \mathrm{C}$. Table 5 shows the diffusion velocities of the steels 37MnB4 and 22MnB5. It becomes clear that the coatings lead to a reduction of the hydrogen transport as they act as a barrier.

Table 5. Determined activation energies and pre-exponential diffusion coefficients from the desorption curves as well as the calculated diffusion coefficients at room temperature.

\begin{tabular}{ccccc}
\hline & 22MnB5 & 22MnB5 + Z140 & 22MnB5 + AS150 & 37MnB4 \\
\hline $\mathrm{E}_{\mathrm{a}}[\mathrm{kJ} / \mathrm{mol}]$ & 28.74 & 38.61 & 55.54 & 30.79 \\
$\mathrm{D}_{0}\left[\mathrm{~m}^{2} / \mathrm{s}\right]$ & $4.29 \times 10^{-6}$ & $9.28 \times 10^{-5}$ & $3.01 \times 10^{-3}$ & $1.27 \times 10^{-5}$ \\
$\mathrm{D}\left(22^{\circ} \mathrm{C}\right)\left[\mathrm{m}^{2} / \mathrm{s}\right]$ & $3.51 \times 10^{-11}$ & $1.36 \times 10^{-11}$ & $4.46 \times 10^{-13}$ & $4.54 \times 10^{-11}$ \\
\hline
\end{tabular}

Empirical test: The measurement shown in Figure 15 (left) shows that the hydrogen effused faster than the samples could be heated. As the temperature is of crucial importance for the calculatory verification, it was averaged from the beginning to the end of the measurement at any time. (see Equation (9)).

$$
\varnothing T_{t}=\frac{1}{t} \cdot \sum_{i=1}^{t} T_{i}
$$

where $Ø T$ is the average temperature; $T$ is the temperature; and $t$ is the time.

Following the determination of the average temperature, the measurements were compared with the desorption curves from the calculation. The calculated comparison was made with the previously determined values from the thermal desorption analysis using Equations (8) and (10). Equation (10) was derived from (8), by removing the Fourier series and convert to $t$ :

$$
\mathrm{t}=\frac{-\ln \left(\frac{\overline{\mathrm{c}} \pi^{2}}{8 \mathrm{c}_{\mathrm{a}}}\right) \mathrm{d}^{2}}{\pi^{2} \mathrm{D}}, \text { with } \mathrm{D}=\mathrm{D}_{0} \mathrm{e}^{\frac{-\mathrm{E}_{\mathrm{a}}}{\mathrm{RT}}}
$$

With both equations a satisfactory agreement with the measurement could be determined on the basis of the previously determined values. Only Equation (10) shows an error if desorption is too low 
(see Figure 15, right). This can be justified by removing the Fourier series. From a desorption of approx. $50 \%$, both calculated curves are almost identical.
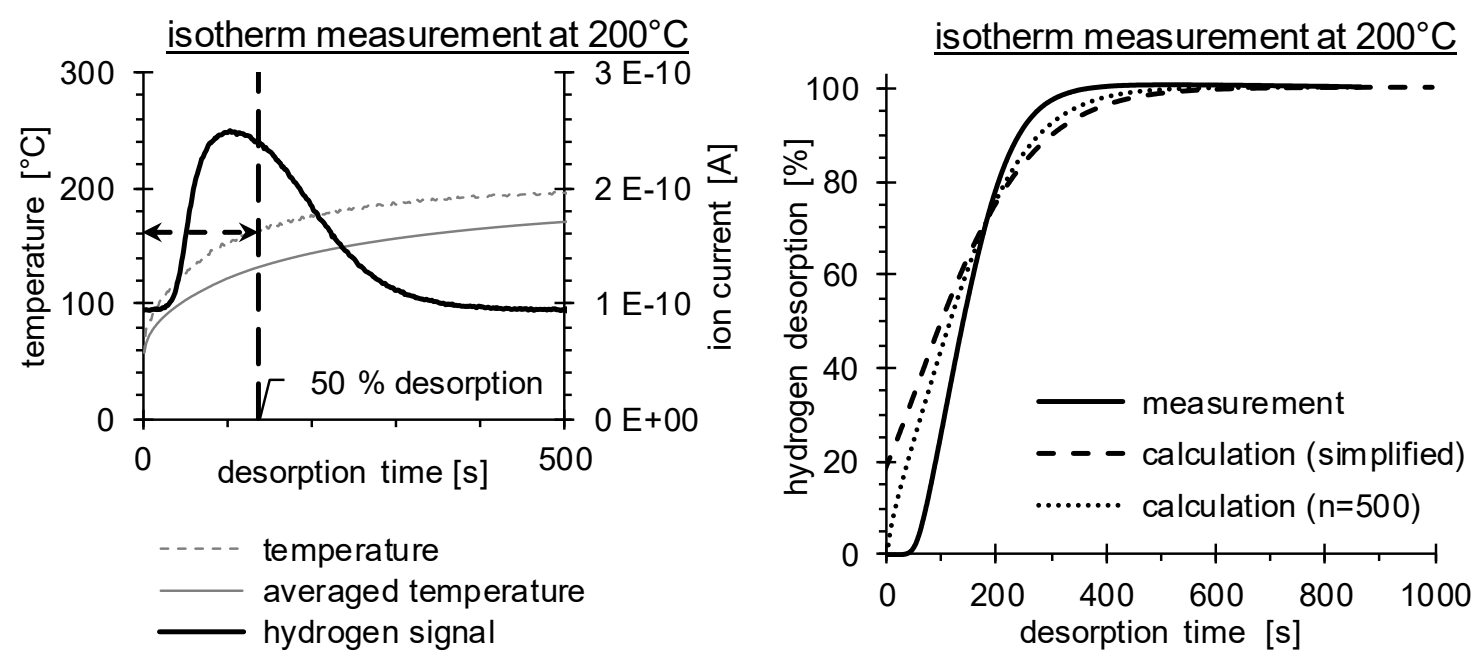

Figure 15. Hydrogen desorption of $22 \mathrm{MnB} 5$ during isothermal heating at $200^{\circ} \mathrm{C}$ (right) and temperature curve (left).

By simply converting the Equation (10) from $t$ to $D$, the diffusion velocity can be determined. Figure 16 shows the calculated diffusion rates at different desorption rates. For comparison, the calculated diffusion coefficients from the previously determined values (T-ramps) are also entered. From a desorption of $50 \%$, a high degree of agreement could be demonstrated. A disadvantage is that no statements can be made about the activation energy and the pre-exponential diffusion coefficient, as is also the case with permeation measurement.

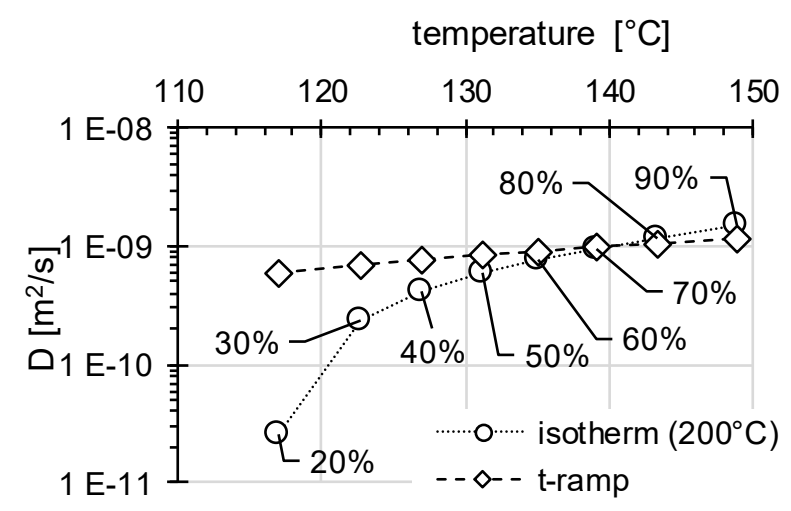

Figure 16. Comparison of diffusion coefficients.

Isothermal determination of the diffusion variables: To determine the $E_{a}$ and the $D_{0}$, Equation (10) can be converted into a linear equation by logarithmizing, as shown below. $D_{0}$ can be calculated from the point of intersection with the ordinate and $E_{a}$ from the slope of the function.

$$
\begin{gathered}
\underbrace{\ln (\mathrm{t})}_{\mathrm{y}}=\underbrace{\ln \left(\frac{-\ln \left(\frac{\overline{\mathrm{c}} \pi^{2}}{8 \mathrm{c}_{\mathrm{a}}}\right) \mathrm{d}^{2}}{\pi^{2} \mathrm{D}_{0}}\right)}_{\mathrm{n}}+\underbrace{\frac{\mathrm{E}_{\mathrm{a}}}{\mathrm{R}}}_{\mathrm{m}} \cdot \underbrace{\frac{1}{\mathrm{~T}}}_{\mathrm{x}} \\
\mathrm{D}_{0}=\frac{-\ln \left(\frac{\overline{\mathrm{c}} \pi^{2}}{8 \mathrm{c}_{\mathrm{a}}}\right) \mathrm{d}^{2}}{\pi^{2} \mathrm{e}^{\mathrm{n}}} \\
\mathrm{E}_{\mathrm{a}}=\mathrm{mR}
\end{gathered}
$$


Similar to the temperature ramps, the logarithmic time at which a certain hydrogen desorption took place is plotted on the ordinate from several measurements as well as the reciprocal of the corresponding mean temperature on the abscissa (see Figure 17). The graph shows different desorption steps of four isothermal measurements $\left(150{ }^{\circ} \mathrm{C}, 200^{\circ} \mathrm{C}, 250^{\circ} \mathrm{C}, 300^{\circ} \mathrm{C}\right)$.

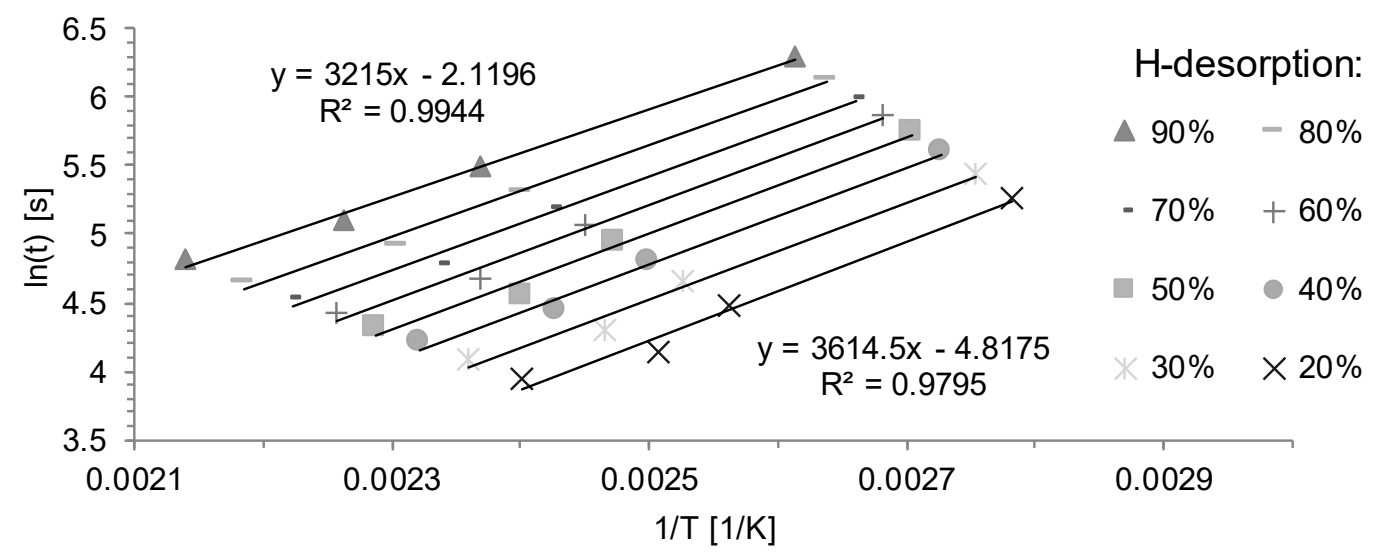

Figure 17. Representation of desorption times at different temperatures and desorption stages.

The linear regressions provide the respective slope and intersections with the ordinate. Below are the calculated values for $D_{0}, E_{a}$ and $D$ at different desorption points (see Figure 18). The values are subject to small fluctuations and $D$ increases with increasing desorption. On average, a value of $2.91 \times 10^{-6} \mathrm{~m}^{2} / \mathrm{s}$ could be determined for $D_{0}$ and $28.76 \mathrm{~kJ} / \mathrm{mol}$ for $E_{a}$. The averaged $D\left(22{ }^{\circ} \mathrm{C}\right)$ was $2.76 \times 10^{-11} \mathrm{~m}^{2} / \mathrm{s}$. All values show a good agreement with those determined before. Strong deviation below $50 \%$ desorption is probably due to the removal of the Fourier series.

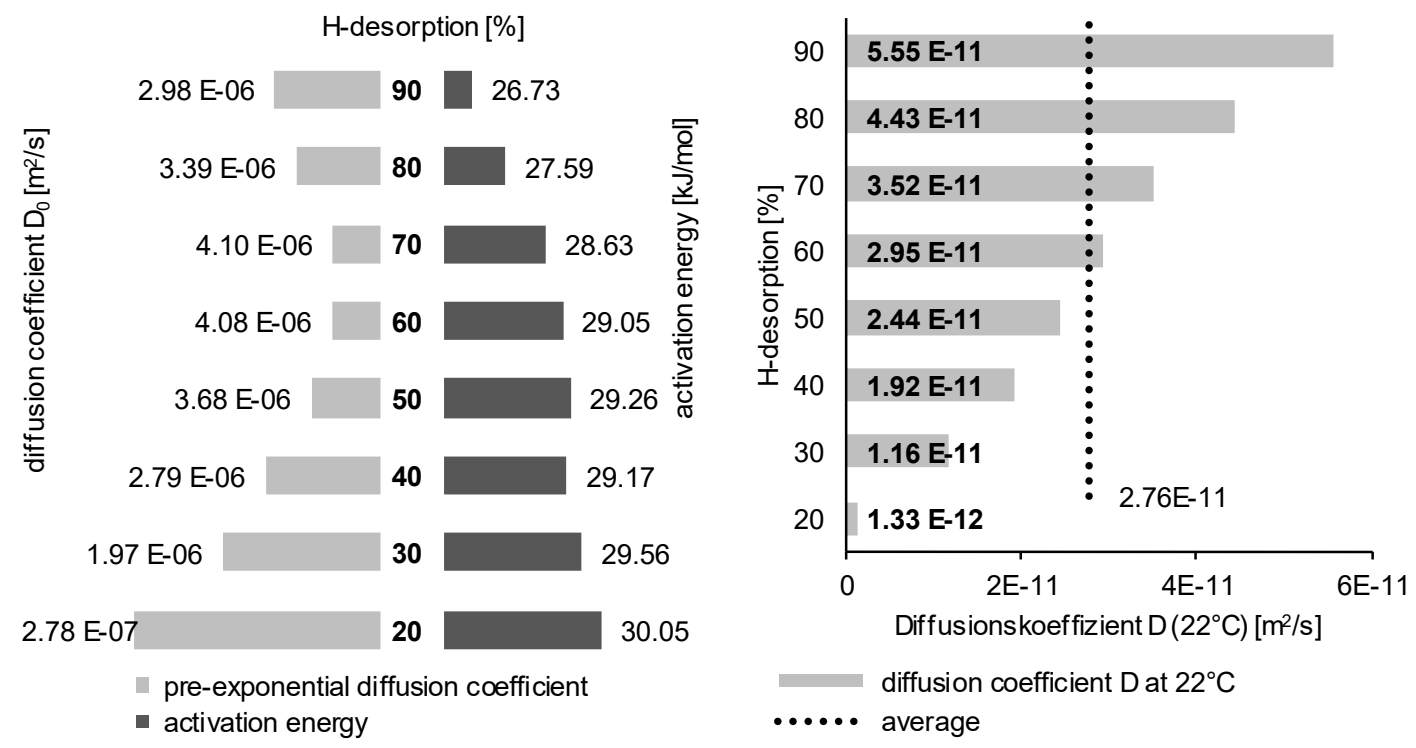

Figure 18. Calculated $E_{a}, D_{0}$ (left) and $D$ (right) for different stages of desorption.

Iterative determination of $D$ by isothermal measurements: In order to improve the results, an iterative procedure was carried out. The iteration process is described in Figure 19. With this method, several $D_{0}$ were given from a selected interval. On the basis of the knowledge gained so far, an area between $1 \times 10^{-6}$ and $5 \times 10^{-6} \mathrm{~m}^{2} / \mathrm{s}$ was defined and divided into equal sections. A starting value of $23 \mathrm{~kJ} / \mathrm{mol}$ was specified for the activation energy. From the starting value of $E_{a}$ and each $D_{0}$ the mean hydrogen concentration at all times of the measurement was calculated with Equations (1) and (8). The Fourier series was determined to $n=500$ and the temperature was averaged from 
the beginning of the measurement to the respective measured value. The absolute deviation of the calculated desorption is then determined from the analysis with the measured desorption. At the same time, the activation energy was increased by any value $i$ (here: $0.01 \mathrm{~kJ} / \mathrm{mol}$ ) and the absolute deviation from the measurement was determined exactly as before. If the calculation with the increased activation energy has a smaller deviation than that of the initial value, this deviation is increased by $i$. This iteration is repeated for all pre-exponential diffusion coefficients until no further improvement occurs. The calculated desorption curves at the beginning of the iteration as well as an isothermal measurement at $200{ }^{\circ} \mathrm{C}$ are shown in the left partial image of Figure 20.

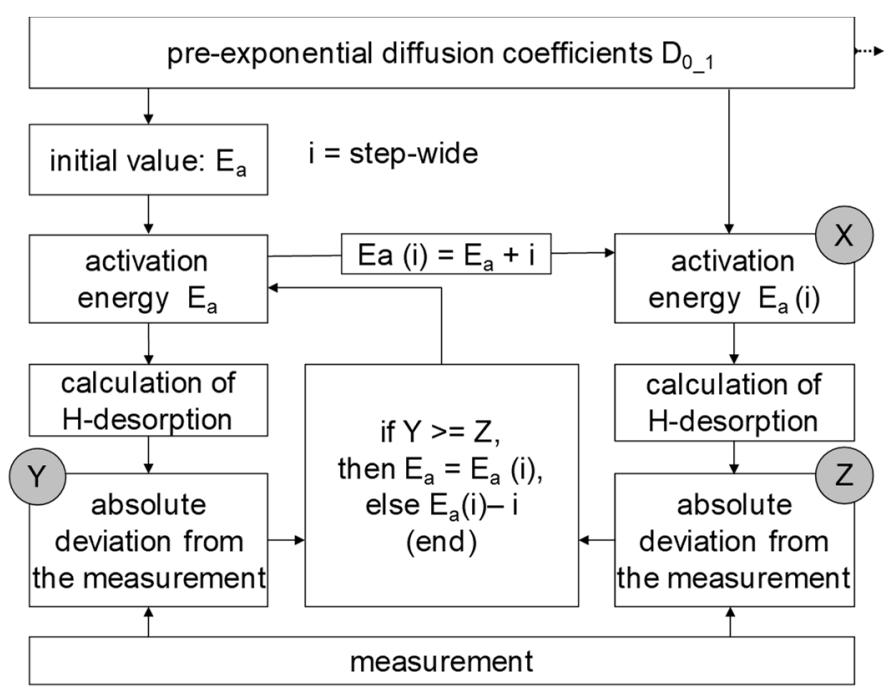

Figure 19. The procedure of the iteration.
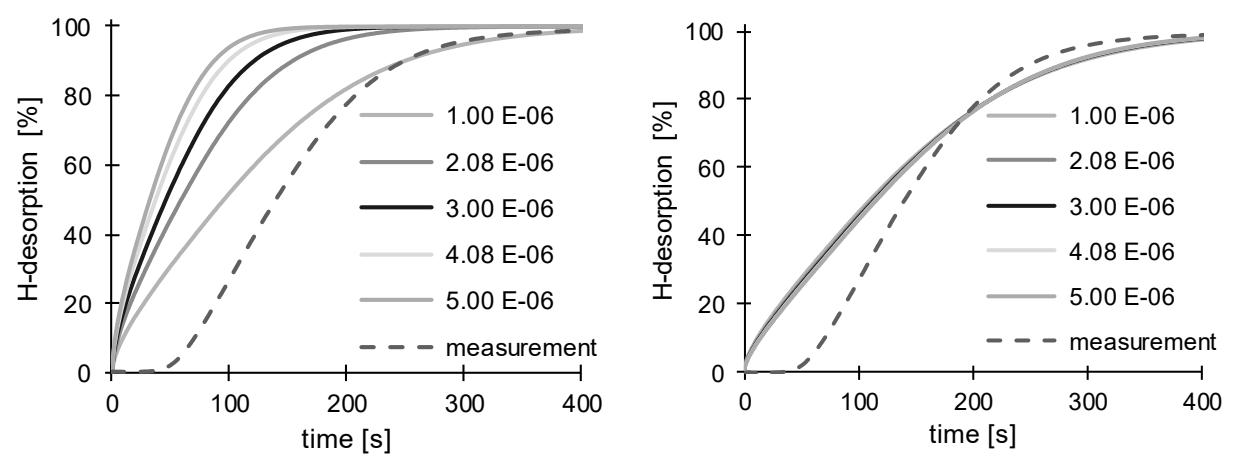

$\begin{array}{cc}D_{0} & E_{a} \\ {\left[\mathrm{~m}^{2} / \mathrm{s}\right]} & {[\mathrm{kJ} / \mathrm{mol}]} \\ 1 \times 10^{-6} & 23.66 \\ 2 \times 10^{-6} & 26.20 \\ 3 \times 10^{-6} & 27.48 \\ 4 \times 10^{-6} & 28.55 \\ 5 \times 10^{-6} & 29.26\end{array}$

Figure 20. Calculated desorption curves at the beginning (left) and after completion of the iteration (right) by means of an isothermal $200{ }^{\circ} \mathrm{C}$-measurement.

In this way, a suitable activation energy was determined for each pre-exponential diffusion coefficient, which, however, leads to a minimal deviation from the measurement. Figure 20-right illustrates the problem. It shows that all characteristic curves are congruent. In addition to the graph, the predefined pre-exponential diffusion coefficients are shown with the determined activation energies, which lead to the smallest absolute deviation. It becomes clear that the $E_{a}$ are distributed over a wide range depending on $D_{0}$.

The true value was calculated by comparison with several measurements at different temperatures $\left(150{ }^{\circ} \mathrm{C}, 200{ }^{\circ} \mathrm{C}, 250^{\circ} \mathrm{C}, 300^{\circ} \mathrm{C}\right)$. The fact that $E_{a}$ and $D_{0}$ must be constant at different temperatures for hydrogen diffusion in the material was exploited. For this purpose, the standard deviation of the activation energies was formed from several measurements. The pre-exponential diffusion coefficient with the activation energies showing the smallest standard deviation among each other is the true value (see Figure 21). The figure shows a clear minimal turning point of the standard deviation. This means 
that the activation energy varies the least in the minimum function, whereby it can be concluded that the value pairs determined there reflect the hydrogen diffusion in the material.

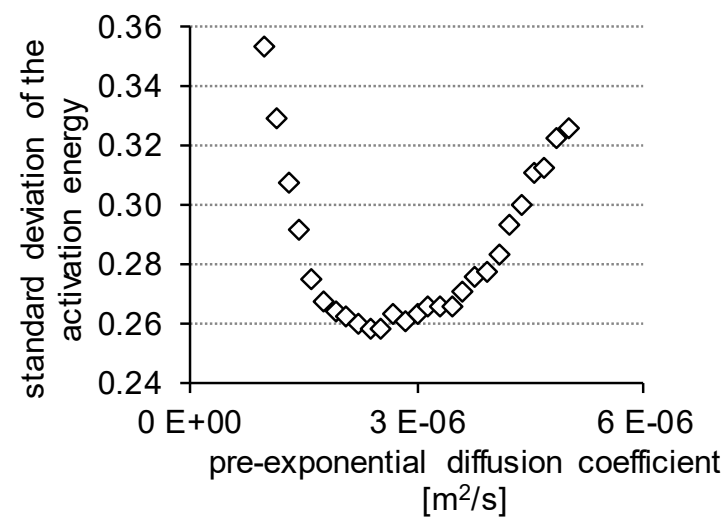

Figure 21. Representation of the standard deviation.

Table 6 shows an extract from the iteration procedure performed, with the specified pre-exponential diffusion coefficients as well as the determined activation energies of the respective measurement series. In this case, the $D_{0}$ of $2.38 \times 10^{-6} \mathrm{~m}^{2} / \mathrm{s}$ had the smallest standard deviation (0.258). The corresponding $E_{a}$ corresponded on average to $26.67 \mathrm{~kJ} / \mathrm{mol}$. The calculated diffusion coefficient (at $22{ }^{\circ} \mathrm{C}$ ) was $4.54 \times 10^{-11} \mathrm{~m}^{2} / \mathrm{s}$.

Table 6. Extract from the iteration.

\begin{tabular}{ccccccccc}
\hline $\boldsymbol{D}_{\mathbf{0}}\left[\times \mathbf{1 0}^{\mathbf{- 6}} \mathbf{~ m}^{\mathbf{2}} / \mathrm{s}\right]$ & 1.00 & 2.08 & 2.38 & 3.00 & 4.08 & 4.23 & 5.00 & \\
\hline $150^{\circ} \mathrm{C}$ & 24.02 & 26.34 & 26.78 & 27.51 & 28.48 & 28.60 & 29.13 & \\
$200^{\circ} \mathrm{C}$ & 23.66 & 26.20 & 26.69 & 27.48 & 28.55 & 28.68 & 29.26 & \\
$250^{\circ} \mathrm{C}$ & 23.16 & 25.81 & 26.31 & 27.13 & 28.26 & 28.39 & 28.99 & $E_{a}$ \\
$300^{\circ} \mathrm{C}$ & 23.59 & 26.39 & 26.91 & 27.77 & 28.94 & 29.09 & 29.74 & {$[\mathrm{~kJ} / \mathrm{mol}]$} \\
standard deviation & 0.3528 & 0.2626 & 0.2580 & 0.2629 & 0.2834 & 0.2934 & 0.3259 & \\
average & 23.60 & 26.19 & 26.67 & 27.47 & 28.56 & 28.69 & 29.28 & \\
$D\left(22^{\circ} \mathrm{C}\right)\left[\times 10^{-11} \mathrm{~m}^{2} / \mathrm{s}\right]$ & 6.64 & 4.82 & 4.54 & 4.12 & 3.60 & 3.54 & 3.29 & \\
\hline
\end{tabular}

\section{Conclusions}

For the permeation measurements, various influencing factors were investigated and their effect on the result evaluated. Based on the thermal desorption analyses carried out, it was possible to determine approximately constant values for the activation energy and the pre-exponential diffusion coefficient. They allow a calculation of the hydrogen transport behaviour over a wide temperature range.

With all procedures performed, almost identical values for the $E_{a}, D_{0}$ and $D$ could be determined. The large number of methods and results indicates a high degree of reliability of the results. Figure 22 summarizes the determined diffusion velocity from the different methods. For the sake of completeness, the diffusion velocities for the coating systems were included.

A comparison with the values found in the literature confirms the determined diffusion coefficients. In [23] a value of $4.5 \times 10^{-11} \mathrm{~m}^{2} / \mathrm{s}$ is mentioned for the $22 \mathrm{MnB} 5$, in [24] a value of $3.5 \times 10^{-11} \mathrm{~m}^{2} / \mathrm{s}$ (mean value) and in [25] $5.5 \times 10^{-11} \mathrm{~m}^{2} / \mathrm{s}$ at room temperature. For the material $22 \mathrm{MnB} 5$ with an AS150 coating, a diffusion velocity of $1.8 \times 10^{-13} \mathrm{~m}^{2} / \mathrm{s}$ was determined.

The results of the work allow a calculation of the hydrogen transport behaviour. The exposure time and thus the risk of HACC can be estimated mathematically. Furthermore, the necessary hydrogen annealing conditions can be calculated as a function of material thickness, temperature and time. (see Figure 23 and $[22,26])$. 


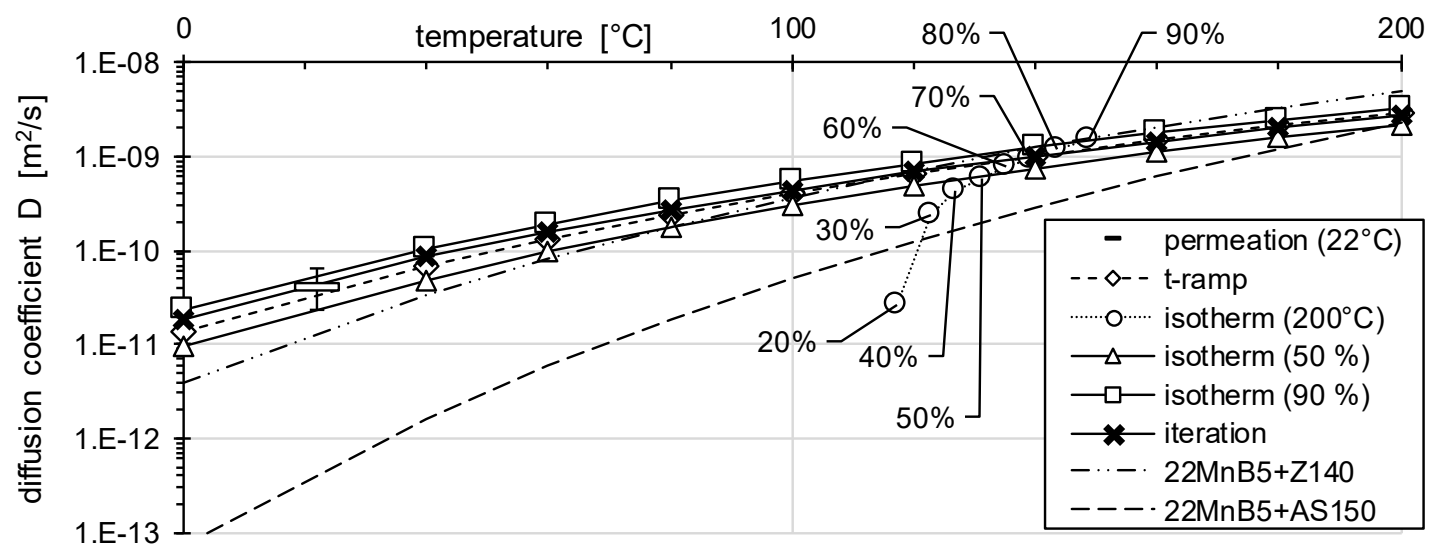

Figure 22. Summary and comparison of the determined diffusion velocities for 22MnB5.

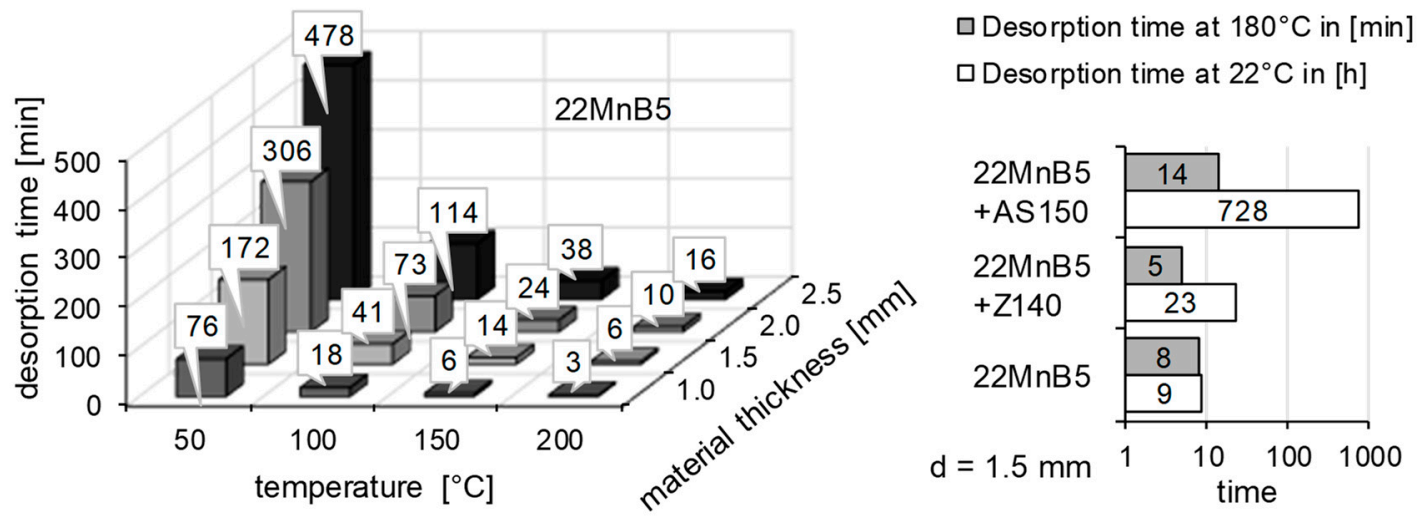

Figure 23. Calculated desorption times for the quenched and tempered steel 22MnB5 (left) and their coating concepts (right) under various conditions.

The times were calculated with Equation (10) and describe the duration for a 99\% hydrogen desorption. The required values were taken from the temperature ramp measurements. It should be noted that the heating time was not taken into account in the calculations. Especially at room temperature the hydrogen barrier of the coatings becomes clear. As the temperature rises, the coatings become increasingly permeable.

In future investigations, further industry-relevant coating concepts will be investigated with regard to their hydrogen barrier effect. One example is a galvanically-applied pure zinc and zinc-nickel coating.

Author Contributions: Conceptualization, M.K.; investigation, M.K.; data curation, M.K.; writing, M.K. and N.M.; writing-review and editing, M.K. and N.M.; supervision, S.J.

Funding: This research was funded by the Federal Ministry of Education and Research (BMBF), grant number 13XP5025E.

Acknowledgments: The present work was funded by the Federal Ministry of Education and Research (BMBF) within the framework of the joint project "ELOBEV-Research into electrolytic coating systems for connecting elements made of high-strength materials" under the funding code 13XP5025E.

Conflicts of Interest: The authors declare no conflict of interest.

\section{References}

1. Lechler, J. Beschreibung und Modellierung des Werkstoffverhaltens von presshärtbaren Bor-Manganstählen; Meisenbach GmbH: Bamberg, Germany, 2009.

2. Li, D.; Chrysanthou, A.; Patel, I.; Williams, G. Self-piercing riveting-A review. Int. J. Adv. Manuf. Technol. 2017, 92, 1777-1824. [CrossRef]

3. Paatsch, W. Wasserstoffbestimmung und Wasserstoffversprödung-Sinn und Nutzen. Galvanotechnik 2011, 102, 48-55. 
4. $\quad$ DIN 50969-1. Vermeidung fertigungsbedingter wasserstoffinduzierter Sprödbrüche bei hochfesten Bauteilen aus Stahl-Teil 1: Vorbeugende Maßnahmen; Deutsches Institut für Normung: Berlin, Germany, 2009.

5. Wendler-Kalsch, E. Grundlagen und Mechanismen der Wasserstoff-induzierten Korrosion metallischer Werkstoffe. In Wasserstoff und Korrosion; Kuron, D., Ed.; Irene Kuron: Bonn, Germay, 2000; pp. 7-53.

6. DIN EN ISO 15330. Verbindungselemente Verspannungsversuch zur Entdeckung von Wasserstoffversprödung, Verfahren mit parallelen Auflageflächen; Deutsches Institut für Normung: Berlin, Germany, 1999.

7. Venezuela, J.; Liu, Q.; Zhang, M.; Zhou, Q.; Atrens, A. A review of hydrogen embrittlement of martensitic advanced high-strength steels. Corros. Rev. 2016, 34, 153-186. [CrossRef]

8. Kunze, E.H. Korrosion und Korrosionsschutz; Wiley-VCH: Weinheim, Germany, 2001.

9. Shreir, L.L. Übersicht der elektrochemischen Methoden zur Untersuchung von Wasserstoffversprödung und Spannungsrißkorrosion. Mater. Corros. 1970, 21, 613-629. [CrossRef]

10. Tostmann, K.H. Ursachen und Vermeidung. In Korrosion; Wiley-VCH: Weinheim, Germany, 2001.

11. Wranglén, G. Korrosion und Korrosionsschutz: Grundlagen, Vorgänge, Schutzmaßnahmen, Prüfung; Springer: Berlin, Germany, 1985.

12. Lange, G.; Pohl, M. Systematische Beurteilung Technischer Schadensfälle; Wiley-VCH: Weinheim, Germany, 2014.

13. Kaesche, H. Die Korrosion der Metalle: Physikalisch-Chemische Prinzipien und aktuelle Probleme, 3rd ed.; Springer: Berlin, Germany, 2011.

14. Neuhaus, D. Method for measuring chemical diffusion coefficients in solids. Appl. Phys. A 2010, 100, 991-1000. [CrossRef]

15. Shewmon, P.; Shen, Y.L.; Shen, C.H.; Meshii, M. Analysis of diffusion controlled release of hydrogen from nickel and inconel 600. Acta Metall. 1989, 37, 1913-1921. [CrossRef]

16. Heumann, T. Diffusion in Metallen. Grundlagen, Theorie, Vorgänge in Reinmetallen und Legierungen; Springer: Berlin, Germany, 1992.

17. Seeger, D.M. Wasserstoffaufnahme und -diffusion in Schweißnahtgefügen hochfester Stähle. Ph.D. Thesis, Helmut-Schmidt-Univ. der Bundeswehr, Hamburg, Germany, 2005.

18. DIN EN ISO 17081: Elektrochemisches Verfahren zur Messung der Wasserstoff-Permeation und zur Bestimmung von Wasserstoffaufnahme und-transport in Metallen; Deutsches Institut für Normung: Berlin, Germany, 2014.

19. Crank, J. The Mathematics of Diffusion, 2nd ed.; Clarendon Press: Oxford, UK, 1975.

20. Thyssenkrupp Steel Europe AG: Borlegierter Einsatz: und Vergütungsstahl. Available online: https://www. thyssenkrupp-steel.com/de/produkte/mittelband/produktdetails/borlegierter-sonderbaustahl/ (accessed on 24 July 2019).

21. Addach, H.; Berçot, P.; Rezrazi, M.; Takadoum, J. Study of the electrochemical permeation of hydrogen in iron. Corros. Sci. 2009, 51, 263-267. [CrossRef]

22. Kuhlmann, M.; Schwedler, O.; Holtschke, N.; Jüttner, S. Consideration of hydrogen transport in press-hardened 22MnB5. Mater. Test. 2015, 57,977-984.

23. Georges, C.; Machedo, T.; Drillet, P. Measurements and modelling of hydrogen desorption at room temperature in Al-Si-coated boron steel. In Proceedings of the Steely Hydrogen Conference Proceedings, Genth, Belgium, 28-29 September 2011; pp. 77-88.

24. Weczera, S.; Rhode, M.; Sunderkötter, C. Laboratory experiments on press hardened steels in different delivered states exposed to hydrogen. In Proceedings of the Hot Sheet Metal Forming of high-performance Steel, Luleå, Sweden, 31 May-3 June 2015; Steinhoff, K., Oldenburg, M., Prakash, B., Eds.; Wissenschaftliche Scripten: Toronto, ON, Canada, 2015; pp. 45-53.

25. Georges, C.; Sturel, T.; Drillet, P. Absorption/desorption of diffusible hydrogen in aluminized boron steel. ISIJ Int. 2013, 53, 1295-1304. [CrossRef]

26. Kuhlmann, M.; Schwedler, O.; Jüttner, S. Betrachtung des Wasserstoffverhaltens beim Formhärten von 22MnB5 mit Aluminium-Silizium-Überzug. In Proceedings of the 11. Erlanger Workshop Warmblechumformung: Tagungsband zum 11. Erlanger Workshop Warmblechumformung, Erlangen, Bavaria, Germany, 17 November 2016; Meisenbach GmbH: Bavaria, Germany, 2016.

(C) 2019 by the authors. Licensee MDPI, Basel, Switzerland. This article is an open access article distributed under the terms and conditions of the Creative Commons Attribution (CC BY) license (http://creativecommons.org/licenses/by/4.0/). 